\title{
Citrus orchard evapotranspiration: Comparison between eddy covariance measurements and the FAO-56 approach estimates
}

\author{
SALAH ER-RAKI ${ }^{1}$, ABDELGHANI CHEHBOUNI ${ }^{2}$, NOURA GUEMOURIA ${ }^{3}$, \\ JAMAL EZZAHAR $^{1}$, SAID KHABBA ${ }^{3}$, GILLES BOULET ${ }^{2}$ \& LAHOUCINE HANICH $^{1}$ \\ ${ }^{1}$ Center for Research on Water in Arid and Semi-arid Environments, Faculty of Sciences and Technology, Cadi Ayyad \\ University, Marrakech, Morocco, ${ }^{2}$ CESBIO (Centre d'Etudes Spatiales de la Biosphère), Toulouse, France, and ${ }^{3}$ FSSM \\ (Faculty of Sciences Semlalia), Cadi Ayyad University, Marrakech, Morocco
}

\begin{abstract}
The aim of this study was to use the FAO-56 single and dual crop coefficient approaches to estimate actual evapotranspiration $\left(\mathrm{ET}_{\mathrm{a}}\right.$ ) over an irrigated citrus orchard under drip and flood irrigations in Marrakech, Morocco. The results showed that, by using crop coefficients suggested in the FAO-56 paper, the performance of both approaches was poor for two irrigation treatments. The Root Mean Squared Error (RMSE) between measured and simulated ET $\mathrm{a}_{\mathrm{a}}$ values over the citrus orchard under drip irrigation was about 1.43 and $1.27 \mathrm{~mm} /$ day for the single and dual approaches, respectively, while the corresponding statistics for the orchard irrigated by the flooding technique was 1.87 and $2.48 \mathrm{~mm} / \mathrm{day}$.

After determination of the appropriate values of the crop coefficient $\left(\mathrm{K}_{\mathrm{c}}\right)$ based on eddy covariance measurements of $\mathrm{ET}_{\mathrm{a}}$, the performance of both approaches greatly improved. The obtained $\mathrm{K}_{\mathrm{c}}$ values were lower than the FAO- 56 values by about $20 \%$. The low $\mathrm{K}_{\mathrm{c}}$ values obtained reflect the practice of drip irrigation for one field and the low value of cover fraction for the other field. Additionally, the efficiency of the irrigation practices was investigated by comparing the measured $\mathrm{K}_{\mathrm{c}}$ for two fields. The results showed that a considerable amount of water was lost by direct soil evaporation from the citrus orchard irrigated by flooding technique.
\end{abstract}

Keywords: Crop coefficient, drip and flood irrigation, citrus orchard, semi-arid region

\section{Introduction}

Citrus are one of the main components of agricultural systems in many semi-arid regions around the Mediterranean, and cover more than 1,000,000 ha (FAO 2003). With its Mediterranean climate, Morocco has good potential for citrus production. However, in this region, water is scarce and/or expensive. Therefore, it is necessary to accurately determine water requirements of citrus orchards, in order to determine suitable irrigation schedules and to improve water use efficiency in irrigated agriculture. Good irrigation management requires an accurate quantification of crop evapotranspiration. The most common approach to calculate evapotranspiration (ET) is the FAO-56 method (Allen et al. 1998). This approach is often preferred due to its simplicity and its applicability on an operational basis. Recently, many studies have shown that this approach provides acceptable ET estimates when compared to ground measurements (e.g. Hunsaker et al. 2003, 2005; Vu et al. 2005; Er-Raki et al. 2007, 2008). In the FAO-56 method, crop evapotranspiration (ET) is estimated using a reference evapotranspiration $\left(\mathrm{ET}_{0}\right)$, which represents the atmospheric demand, and the crop coefficient $\left(\mathrm{K}_{\mathrm{c}}\right)$, which depends on ground cover, soil type, irrigation method and crop characteristics. There are two methods to estimate ET: the single and the dual crop coefficients. The single crop coefficient is used for irrigation planning and design, irrigation management, basic irrigation scheduling and real-time irrigation timing for less frequent water applications. The dual crop coefficient, which consists of two coefficients: a basal crop coefficient $\mathrm{K}_{\mathrm{cb}}$ and a soil evaporation coefficient $K_{e}$, is mainly used in research, real-time irrigation scheduling for highly frequent water applications, supplemental irrigation,

Correspondence: Chehbouni Abdelghani, CESBIO (Centre d'Etudes Spatiales de la Biosphère), Toulouse, France. 18 Avenue Edouard Belin, bpi 2801, 31401 Toulouse cedex 9, France. Tel: 335615585 23. Fax: 335615585 00. Email: ghani.chehbouni@cesbio.cnes.fr 
and detailed soil and hydrologic water balance studies (Allen et al. 1998). The crop coefficient changes with growth stages, and can be determined by dividing measured ET with $\mathrm{ET}_{0}$. Allen et al. (1998) have suggested that the crop coefficient values need to be derived empirically for each crop based on lysimeteric data and local climatic conditions. Crop coefficient values for a number of crops in different climatic conditions were proposed by Doorenbose and Pruitt (1977), and later updated by Allen et al. (1998). These values are commonly used in places where local data are not available. However, specific adjustment of crop coefficients in various climatic regions is necessary, since they integrate several factors related to pedological, biophysical, physiological, and aerodynamic processes (Katerji et al. 1991; Testi et al. 2004; Rana et al. 2005; Katerji \& Rana 2006). Although the ET for some citrus orchards has been documented in Morocco (Yacoubi 1982; El Hari 1992), the crop coefficient values for citrus orchards growing in the semi-arid region of southern Morocco are not currently available.

In the present study, we focused on the use of the FAO-56 single and dual crop coefficient approaches to estimate seasonal $\mathrm{ET}_{\mathrm{a}}$ and $\mathrm{K}_{\mathrm{c}}$ of citrus orchards in this region. The specific objectives were to investigate whether the use of the crop coefficient values provided in the FAO-56 paper is appropriate for accurately estimating $\mathrm{ET}_{\mathrm{a}}$ over an irrigated orchard in the semi-arid region of Morocco, and to assess the impact of irrigation method on the performance of the approaches.

\section{Materials and methods}

\section{Site description}

The study was conducted during 2004 and 2005 in two orange tree sites located in the Tensift Al Haouz, Marrakech province, southern Morocco. This area has a semi-arid Mediterranean climate, characterized by low and irregular rainfall with an annual average of about $240 \mathrm{~mm}$ against an $\mathrm{ET}_{0}$ of $1600 \mathrm{~mm} /$ year. The first field named "Saada 1" was planted with

(1) 13-year old mandarin trees, at a spacing of $5 \times 3 \mathrm{~m}$, i.e. to about $70 \%$ cover fraction. The average height of the trees was about $3.15 \mathrm{~m}$. The crop was maintained under well watered conditions, by drip irrigation, supplied every day. Fertilization and pest and weed control were performed. The second field, named "Saada 2", was planted with 15-year-old mandarin trees. The trees were planted in a regular square pattern $(7 \times 7 \mathrm{~m})$ and the cover fraction was about $30 \%$. The average height of the trees was about $3.3 \mathrm{~m}$. The site was periodically surface-irrigated through basin level flood irrigation. Each tree is bordered by a small earthen levy that retains the irrigation water. The irrigation frequency was every one to three weeks, depending on climatic conditions and rainfall, in order to avoid water stress. The amount of water applied during each irrigation event was approximately $40 \mathrm{~mm}$. The soils have high sand and low clay contents (12\% clay, $38 \%$ silt, and $50 \%$ sand). Further details about the sites are given in Ezzahar et al. (in this issue) and Boulet et al. (2006), which provide additional information about Saada 1 and Saada 2, respectively.

\section{Data description}

Meteorological measurements were made using an automated weather station as follows: incoming solar radiation was measured with a Kipp and Zonen, CM5 , air temperature and humidity were measured with Vaisala HMP45C probes, wind speed was measured with A100R anemometers (R.M. Young Company, USA), net radiation was measured with a Kipp and Zonen CNR1 net radiometer placed over the canopy. Six heat flux plates continuously monitored changes in soil heat storage, and rainfall was measured with a FSS500 tipping bucket automatic rain gauge (Campbell Inc., USA). All meteorological measurements were measured at $6 \mathrm{~m}$ height, and were recorded in a data logger (CR10, Campbell Scientific, Logan, UT), sampled at $1 \mathrm{~Hz}$ and averaged over $30 \mathrm{~min}$. Daily average values of climatic data were calculated in order to compute the daily $\mathrm{ET}_{0}$ ( $\mathrm{mm} /$ day), according to the FAO-56 Penman-Monteith parameterization scheme (Allen et al. 1998, 2006).

Two eddy covariance systems were installed over two fields of orange trees to provide continuous measurements of vertical fluxes of heat, water vapour at $6.9 \mathrm{~m}$. The eddy covariance system used consisted of commercially available instrumentation: a 3D sonic anemometer (CSAT3, Campbell Scientific Ltd.) which measured the fluctuations in wind velocity components and temperature, and an open-path infrared gas analyzer (Li7500, Campbell Scientific Ltd.) that measured concentration of water vapour and carbon dioxide. Raw data were sampled at a rate of $20 \mathrm{~Hz}$ and were recorded using CR23X data loggers (Campbell Scientific Ltd.). The halfhourly values of fluxes were later calculated off-line after performing coordinate rotation, correcting the sonic temperature for the lateral velocity and the humidity effects, making frequency integration, and including the mean vertical velocity according to Webb et al. (1980), Schotanus et al. (1983) and Wilczak et al. (2001). The calculation of actual evapotranspiration $\mathrm{ET}_{\mathrm{a}}(\mathrm{mm})$ at a daily time scale was obtained by summing the half-hourly values. $\mathrm{ET}_{\mathrm{a}}$ measurements were taken from a central location of the field, determinated by the frequency 
of the wind direction analysis, to obtain the longest unobstructed wind fetch (Ezzahar et al., in this issue). The size of both fields was large enough so that the required fetch conditions required for eddy covariance are fulfilled. Missing data in some days is due to problems with the power supply.

The performance of flux measurements was assessed by the energy balance closure. By neglecting the term of canopy heat storage and the radiative energy used in photosynthesis (Baldocchi et al. 2000; Testi et al. 2004), the energy balance equation is given by:

$$
\mathrm{R}_{\mathrm{n}}-\mathrm{G}=\mathrm{H}_{\mathrm{EC}}+\mathrm{LvE}_{\mathrm{EC}}
$$

where $R_{n}$ is the net radiation; $G$ is the soil heat flux; $\mathrm{H}_{\mathrm{EC}}$ and $\mathrm{LvE}_{\mathrm{EC}}$ are, respectively, the sensible heat flux and the latent heat flux measured by the eddy covariance system. Figure 1 shows how well the available energy $\left(R_{n}-G\right)$ was balanced by $\left(\mathrm{H}_{\mathrm{EC}}+\mathrm{LvE}_{\mathrm{EC}}\right)$ on a daily time scale over the two study sites. The slope of the regression forced
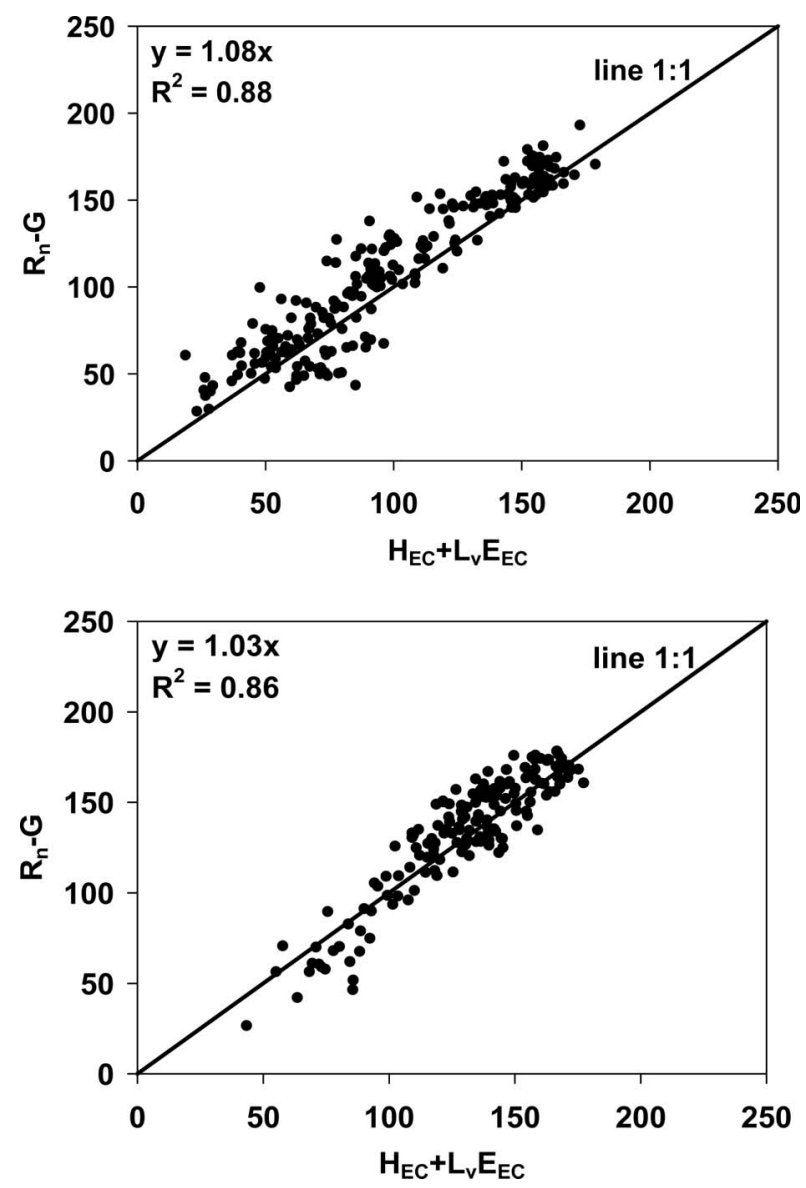

Figure 1. Assessment of energy balance closure. Daily average fluxes of net radiation $\left(R_{n}\right)$ minus the soil heat flux $(G)$ are compared against the sums of sensible $\left(\mathrm{H}_{\mathrm{EC}}\right)$ and latent heat $\left(\mathrm{L}_{\mathrm{v}} \mathrm{E}_{\mathrm{EC}}\right)$ measured by the eddy covariance system over a citrus orchard irrigated by drip irrigation (upper) and by flooding irrigation (lower). through the origin was 1.08 for Saada 1 and 1.03 for Saada 2, indicating that an underestimation of the flux $\left(\mathrm{H}_{\mathrm{EC}}+\mathrm{LvE}_{\mathrm{EC}}\right)$ was less than $10 \%$ of the available energy $\left(R_{n}-G\right)$. These results indicate a good closure of the energy balance, which is in agreement with other studies (Baldocchi et al. 2000; Twine et al. 2000; Testi et al. 2004; Boulet et al. 2006; Ezzahar et al. 2007).

\section{$A$ brief description of FAO-56 method}

In this section, only a brief summary of the FAO-56 approach is provided. The reader can refer to Allen et al. (1998) for more details. In the single crop coefficient approach, the effects of crop transpiration and soil evaporation are combined into a single $\mathrm{K}_{\mathrm{c}}$ coefficient while in the dual crop coefficient approach, the effects of crop transpiration $\left(\mathrm{K}_{\mathrm{cb}}\right)$ and soil evaporation $\left(\mathrm{K}_{\mathrm{e}}\right)$ are determined separately. The overall equations using the single and dual crop coefficient to calculate crop maximal evapotranspiration $\left(\mathrm{ET}_{\mathrm{c}}\right)$ are, respectively:

$$
\begin{gathered}
\mathrm{ET}_{\mathrm{c}}=\mathrm{K}_{\mathrm{c}} * \mathrm{ET}_{0} \\
\mathrm{ET}_{\mathrm{c}}=\left(\mathrm{K}_{\mathrm{cb}}+\mathrm{K}_{\mathrm{e}}\right) * \mathrm{ET}_{0}
\end{gathered}
$$

When the available soil water of the root zone drops below a critical level, crop water stress can occur and reduce $\mathrm{ET}_{\mathrm{c}}$. In the $\mathrm{FAO}-56$ dual procedures, the effects of water stress on $\mathrm{ET}_{\mathrm{c}}$ can be estimated by multiplying $\mathrm{K}_{\mathrm{cb}}$ by the water stress coefficient $\left(\mathrm{K}_{\mathrm{s}}\right)$. When the single crop coefficient is used, the effect of water stress is incorporated into $\mathrm{K}_{\mathrm{c}}$. So actual evapotranspiration, denoted as $\mathrm{ET}_{\mathrm{a}}$ is calculated as (Allen et al. 1998):

$$
\begin{gathered}
\mathrm{ET}_{\mathrm{a}}=\mathrm{K}_{\mathrm{s}} * \mathrm{~K}_{\mathrm{c}} * \mathrm{ET}_{0} \\
\mathrm{ET}_{\mathrm{a}}=\left(\mathrm{K}_{\mathrm{s}} * \mathrm{~K}_{\mathrm{cb}}+\mathrm{K}_{\mathrm{e}}\right) * \mathrm{ET}_{0}
\end{gathered}
$$

Following Equations 3 and 4, three parameters are necessary to determine $\mathrm{ET}_{\mathrm{a}}$ by using the dual approach: $\mathrm{K}_{\mathrm{cb}}, \mathrm{K}_{\mathrm{e}}$ and $\mathrm{K}_{\mathrm{s}}$. Where the single approach is used, only two parameters are needed to determine $\mathrm{ET}_{\mathrm{a}}: \mathrm{K}_{\mathrm{c}}$, and $\mathrm{K}_{\mathrm{s}}$. Soil and crop parameters used for the computation of these coefficients are presented in Table I.

Applicability of FAO-56 in estimation of citrus $\mathrm{ET}_{\mathrm{a}}$ was evaluated. We firstly simulated the time course of $\mathrm{ET}_{\mathrm{a}}$ using the FAO-56 based single and dual crop coefficient approaches with standard values of $\mathrm{K}_{\mathrm{c}}$ and after with the adjusted $\mathrm{K}_{\mathrm{c}}$. The simulation was performed during 2004 for a citrus orchard receiving drip irrigation, and during 2005 for an orchard irrigated by flooding technique. 
Table I. Soil and crop parameters used for calculating actual evapotranspiration (ET $\mathrm{a}_{\mathrm{a}}$ of orange tree irrigated by drip and flooding irrigations, following the procedure described in the FAO Irrigation and Drainage Paper No. 56 (Allen et al. 1998).

\begin{tabular}{|c|c|c|c|c|}
\hline \multirow[b]{2}{*}{ Parameter } & \multicolumn{2}{|c|}{ Orange irrigated by drip } & \multicolumn{2}{|c|}{ Orange irrigated by flooding } \\
\hline & $\begin{array}{c}\text { Standard } \\
\text { values FAO-56 }\end{array}$ & Local values & $\begin{array}{c}\text { Standard } \\
\text { values } \mathrm{FAO}-56\end{array}$ & Local values \\
\hline The lengths of growth stages & \multicolumn{2}{|c|}{$\begin{array}{l}60 / 90 / 120 / \\
95 \text { (days) }\end{array}$} & \multicolumn{2}{|c|}{$\begin{array}{c}60 / 90 / 120 / \\
95 \text { (days) }\end{array}$} \\
\hline Crop coefficient at three stages & $0.7 / 0.65 / 0.7$ & $0.45 / 0.6 / 0.5$ & $0.8 / 0.8 / 0.8$ & $0.58 / 0.55 / 0.6$ \\
\hline Basal crop coefficient at three stages & $0.65 / 0.6 / 0.65$ & $0.35 / 0.55 / 0.45$ & $0.75 / 0.75 / 0.75$ & $0.3 / 0.5 / 0.4$ \\
\hline Depth of soil surface evaporation layer (Ze) & & & & \\
\hline Total evaporable water (TEW) & & & & \\
\hline Readily evaporable water (REW) & & & & \\
\hline Total available water (TAW) & & & & \\
\hline Readily available water (RAW) & & & & \\
\hline Ground cover fraction $\left(f_{c}\right)$ & & & & \\
\hline
\end{tabular}

Ground cover fraction $\left(f_{c}\right)$

\section{Results and discussions}

\section{Evolution of reference evapotranspiration (ET⿰亻}

The evolution of reference evapotranspiration $\left(\mathrm{ET}_{0}\right)$, which is the main input of the FAO-56 model and the most important component in the determination of crop water requirement, was determined. Figure 2 presents the seasonal variations of $\mathrm{ET}_{0}$ calculated according to the FAO-Penman-Monteith equation (Allen et al. 1998). The temporal pattern of $\mathrm{ET}_{0}$ values is typically that of a semi-arid continental climate type. It is characterized by a high climatic demand, with an average accumulated annual $\mathrm{ET}_{0}$ of $1480 \mathrm{~mm}$. The lowest values of $\mathrm{ET}_{0}$ occurred during the winter and autumn $(1.23 \mathrm{~mm} /$ day $)$ and the highest values occurred in the summer $(7.8 \mathrm{~mm} /$ day). Comparing the annual average rainfall $(\approx 240 \mathrm{~mm})$ with the product $\mathrm{K}_{\mathrm{c}}{ }^{\star} \mathrm{ET}_{0}=1036 \mathrm{~mm}$ $\left(\mathrm{K}_{\mathrm{c}}\right.$ is the crop coefficient of citrus trees given in the FAO-56 paper), indicates the necessity to irrigate citrus orchards to avoid water stress and hence obtain a profitable yield.

Simulation of actual evapotranspiration (ETa) by FAO56 single and dual crop coefficient approaches

We simulated the time course of $\mathrm{ET}_{\mathrm{a}}$ using the FAO56 based single and dual crop coefficient approaches over citrus tree using the parameters given in FAO56 tables (Table I). Figure 3 shows the estimated actual $\mathrm{ET}_{\mathrm{a}}$ by the FAO-56 single crop coefficient approach versus the one measured by the eddy covariance system over citrus tree irrigated by drip irrigation (upper panel) and by flooding irrigation (lower panel). It is obvious that the performance of the single crop coefficient approach is poor over both sites. The Root Mean Square Error (RMSE), defined as the square root of the averaged quadratic difference between observations and simulations,

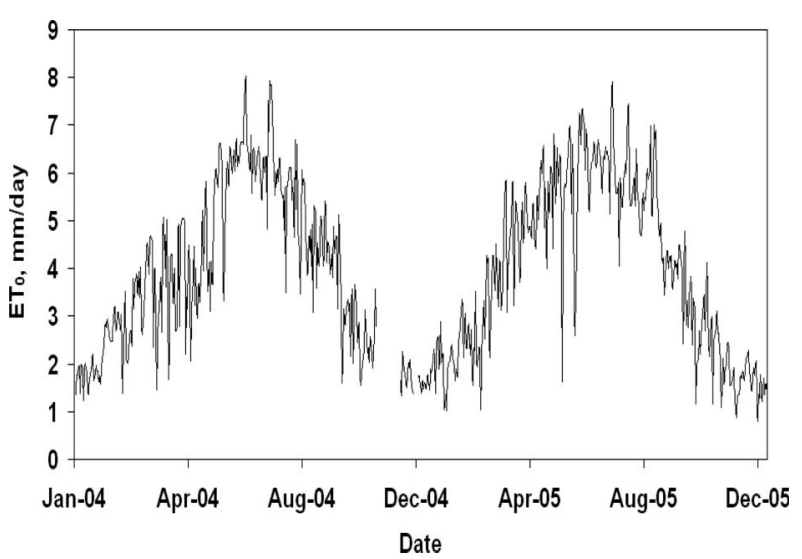

Figure 2. Daily reference evapotranspiration $\mathrm{ET}_{0}$ calculated following the FAO-Penman-Monteith equation during the 2004 and 2005 growing seasons of citrus orchards in the Tensift $\mathrm{Al}$ Haouz basin.

between measured and simulated $\mathrm{ET}_{\mathrm{a}}$ values under drip and flooding irrigations were about 1.43 and $1.87 \mathrm{~mm} /$ day, respectively. A linear regression analysis forced through the origin is presented in the figures. The slopes were 1.44 and 1.51 for Saada 1 and Saada 2, respectively. The model tends to overestimate actual $\mathrm{ET}_{\mathrm{a}}$ over both fields (Saada 1 and Saada 2) by about $44 \%$ and $51 \%$, respectively. This behavior might be explained by the fact that the values of $K_{c}$ are not appropriate. Standard $K_{c}$ values given in FAO-56 were established for specific conditions which vary substantially from region to region, with climate and cropping conditions, and with crop variety. Therefore, the determination of appropriate $\mathrm{K}_{\mathrm{c}}$ values is required in order to improve estimates of crop water requirements.

Similarly, Figure 4 shows the estimated $\mathrm{ET}_{\mathrm{a}}$ by the FAO-56 dual crop coefficient approach versus the one measured by the eddy covariance system over citrus trees irrigated by drip irrigation (upper panel) 

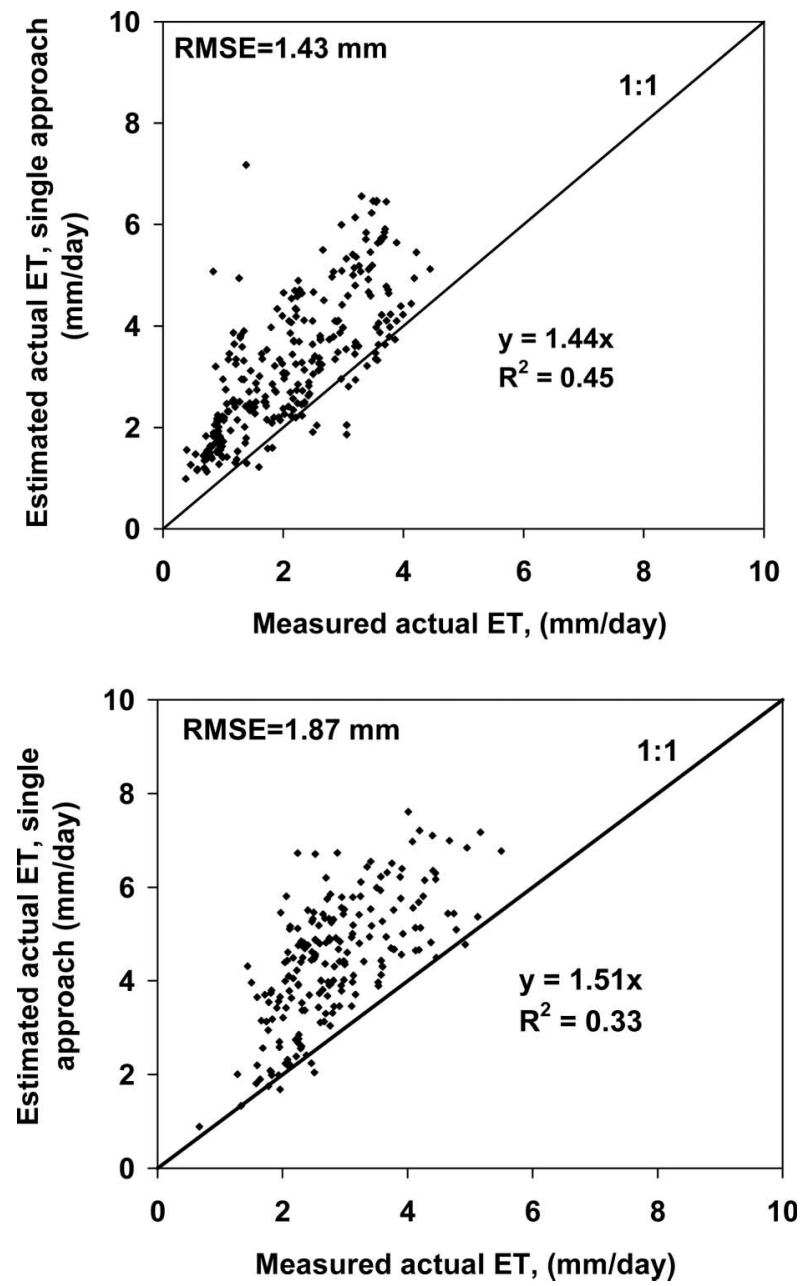

Figure 3. Actual $\mathrm{ET}_{\mathrm{a}}$ estimated by the single approach versus the one measured by the eddy covariance system over the citrus orchard irrigated by drip irrigation (upper) and by flooding irrigation (lower) by using the $\mathrm{K}_{\mathrm{c}}$ values given in FAO-56.

and by flooding irrigation (lower panel). As for the single approach, the performance of the dual approach was very poor, especially over the orchard irrigated by the flood technique. The RMSE between measured and simulated $\mathrm{ET}_{\mathrm{a}}$ values under drip and flooding irrigations were 1.27 and $2.48 \mathrm{~mm} /$ day, respectively. It is clear that the model tends to overestimate $\mathrm{ET}_{\mathrm{a}}$ values over both fields. The overestimation is larger (about $77 \%$ ) for the field irrigated by the flooding technique. This behavior might be explained by two factors: (1) the values of $\mathrm{K}_{\mathrm{cb}}$ suggested by Allen et al. (1998) are not valid for the two fields; (2) the FAO-56 dual crop coefficient approach predicts high soil evaporation during the wetting event, especially for the flood irrigation.

According to these results, a clear overestimate of actual $\mathrm{ET}_{\mathrm{a}}$ by both approaches (single and dual) over the two fields is evident. Thus, a local estimation of $\mathrm{K}_{\mathrm{c}}$ and $\mathrm{K}_{\mathrm{cb}}$ is needed to estimate accurately the crop

(3) water requirement of orange orchards.
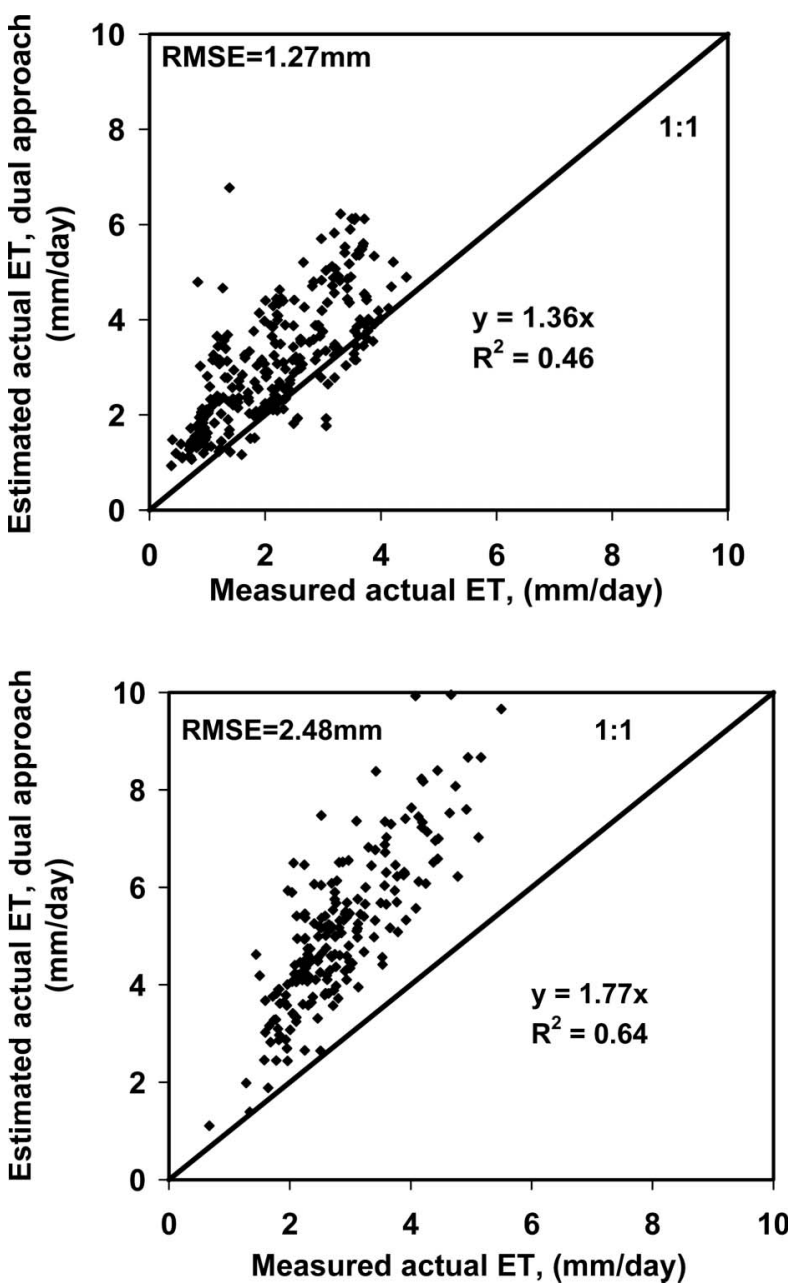

Figure 4. Actual $\mathrm{ET}_{\mathrm{a}}$ estimated by the dual approach versus the one measured by the eddy covariance system over the citrus orchard irrigated by drip irrigation (upper) and by flooding irrigation (lower) by using the $\mathrm{K}_{\mathrm{cb}}$ values given in FAO-56.

\section{Derived crop coefficient}

Since we are interested in the determination of crop water requirement and hence irrigation management, crop coefficient values are crucial for planning and management of water resources. Figure 5 shows the computed crop coefficient $\mathrm{K}_{\mathrm{c}}$ values following the FAO-56 single and dual crop coefficient approaches for orange trees irrigated by drip irrigation (upper panel) and by flood irrigation (lower panel) as well as the basal crop coefficient $\left(\mathrm{K}_{\mathrm{cb}}\right)$. The variation of $\mathrm{K}_{\mathrm{c}}$ and $\mathrm{K}_{\mathrm{cb}}$ at mid-season stage corresponds to the adjustment of both parameters with relative humidity and wind speed, as suggested by Allen et al. (1998) (equation 62 in FAO-56). The values of $\mathrm{K}_{\mathrm{c}}$ and $\mathrm{K}_{\mathrm{cb}}$ were determined based on eddy covariance measurements of $\mathrm{ET}_{\mathrm{a}}$ and $\mathrm{ET}_{0}$ estimated by the FAO-Penman-Monteith method. The $\mathrm{K}_{\mathrm{c}}$ values for the orchard irrigated by drip and flooding irrigations at three crop growth stages (initial, midseason and maturity) were about $0.45,0.6,0.5$ and

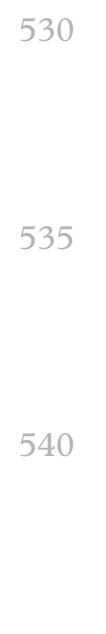


$0.58,0.55,0.6$, respectively (Table I). These values were lower than those suggested by the FAO-56 paper (Table I). The low $\mathrm{K}_{\mathrm{c}}$ values obtained reflect the effect of practising localized drip irrigation that reduces soil evaporation. These results are considered reasonable since they support the reported conclusions of many studies regarding the significant reduction in crop water requirement when localized irrigation is practiced (Allen et al. 1998; Amayreh \& Al-Abed, 2004; Er-Raki et al. 2006). For the orchard irrigated by the flooding technique, the reduction in the $\mathrm{K}_{\mathrm{c}}$ values can be explained by the low value of cover fraction (about 30\%), which can reduce transpiration $\left(\mathrm{K}_{\mathrm{cb}}\right)$ when the soil surface is dry.

As shown in Figure 5, the difference between the total crop coefficient computed by the dual approach and the basal crop coefficient during wetting events (irrigation or rainfall) corresponds to the soil evaporation coefficient. As expected, the dual crop coefficient approach calculates the actual increase in crop coefficient $\mathrm{K}_{\mathrm{c}}$ for each day as a function of plant development $\mathrm{K}_{\mathrm{cb}}$ and the wetness of the soil surface (soil evaporation). It can be seen that after the wetting events (rainfall or irrigation), soil evaporation was higher for flooding irrigation than the drip technique.

After the determination of the appropriate crop coefficient $\mathrm{K}_{\mathrm{c}}$, the FAO-56 single crop coefficient approach gives acceptable estimates of $\mathrm{ET}_{\mathrm{a}}$ for citrus orchards under different types of irrigation (flooding and drip) in the semi-arid region of Tensift $\mathrm{Al}$
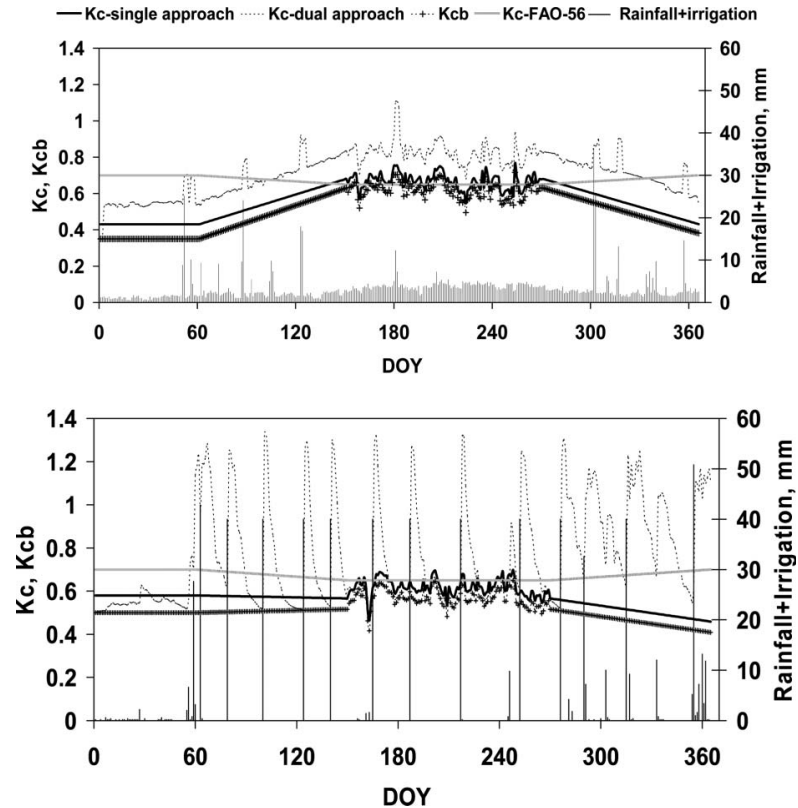

Figure 5. Computed crop coefficient by the FAO-56 single and dual crop coefficient approaches for a citrus orchard irrigated by drip irrigation (upper) and by flooding irrigation (lower). Crop coefficients suggested by FAO-56 (Kc-FAO-56) are plotted in the same figures. DOY $=$ day of year.
Haouz. The RMSE was reduced from 1.43 to $1.15 \mathrm{~mm} /$ day for the orchard irrigated by drip irrigation, and from 1.87 to $0.82 \mathrm{~mm} /$ day for the orchard irrigated by flood irrigation, corresponding to relative reductions of $20 \%$ and $57 \%$, respectively. The performance of the single crop coefficient approach is lower for the orchard irrigated by the drip technique. This may be due to an overestimate of soil evaporation, which is included implicitly in the single crop coefficient.

Similarly, after the determination of the local basal crop coefficient $\mathrm{K}_{\mathrm{cb}}$, the FAO-56 dual crop coefficient approach gives acceptable results of $\mathrm{ET}_{\mathrm{a}}$ under both types of irrigation. The RMSE between measured and simulated $\mathrm{ET}_{\mathrm{a}}$ values under drip and flooding irrigations were about 0.97 and $1.26 \mathrm{~mm} /$ day, respectively. The model still overestimates $\mathrm{ET}_{\mathrm{a}}$ values by about $34 \%$ over the field irrigated by the flooding technique. This is due to the fact that the FAO-56 dual crop coefficient approach predicts high soil evaporation due to the lower cover fraction (about 30\%) for the orchard irrigated by flooding.

These results suggest that the single crop coefficient approach can be used to derive a good estimate of water consumption of citrus orchards irrigated by the flooding technique with less frequent water applications, while the dual approach can be used for real-time irrigation scheduling with highly frequent water applications, as in the case of the dripirrigated citrus orchards. These results are in agreement with the recommendations suggested in the FAO-56 paper by Allen et al. (1998).

\section{Irrigation efficiency assessment}

The efficiency of the irrigation practices over two orange orchards was investigated. For that, we compared the measured $\mathrm{K}_{\mathrm{c}}$ for both sites during the period when rainfall is absent (from DOY 116 to DOY 160 during 2005) (Figure 6). The irrigation

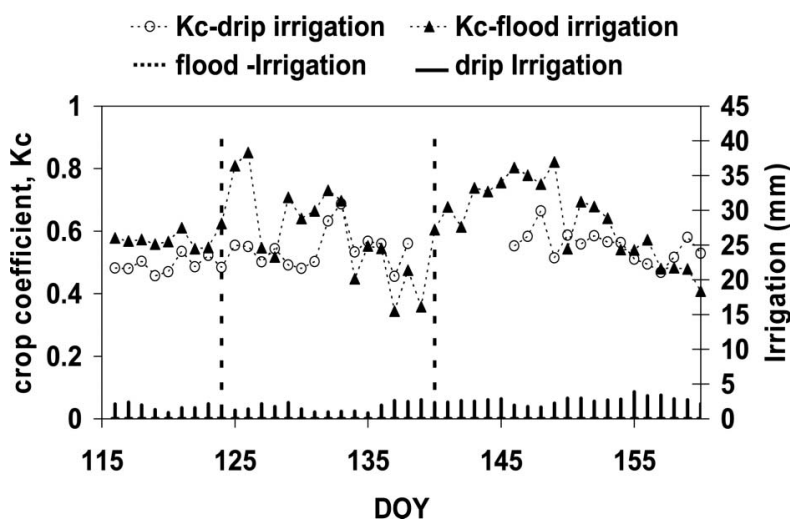

Figure 6. Comparison between the measured crop coefficients over the two sites, one irrigated by drip irrigation and the other by flooding irrigation. 
events over each field are presented in the same figure. As can be seen in this figure, the $K_{c}$ of the orchard irrigated by flooding increased after irrigation and reaches 0.80 . This value is higher than that corresponding to the orchard irrigated by the drip technique (0.55). This overestimate, of about $45 \%$, could be explained by soil evaporation, which is higher for the flooding irrigation, especially when the cover fraction $\left(f_{c}\right)$ is lower, i.e. for the Saada 2 site $\left(\mathrm{f}_{\mathrm{c}} \approx 30 \%\right)$. To save this considerable amount of water lost by soil evaporation, which is not used by the plant, the choice of an adequate irrigation method, like drip irrigation, is advisable. A good evaluation of the amount of water lost by direct soil evaporation needs a partitioning of total evapotranspiration into its soil evaporation and plant transpiration components. This can be achieved through sap flow or isotope measurements (Williams et al. 2004, Rana et al. 2005). Therefore, separate measurements of transpiration and soil evaporation are desirable.

\section{Conclusions}

The general objective of this study was to use the FAO-56 single and dual crop coefficient approaches to estimate actual evapotranspiration $\left(\mathrm{ET}_{\mathrm{a}}\right)$ over an irrigated citrus orchard under drip and flood irrigations in Marrakech, Morocco. The results showed that, by using crop coefficients suggested by the FAO-56 paper, both approaches overestimate $\mathrm{ET}_{\mathrm{a}}$ for both irrigation methods.

After obtaining the appropriate values of crop coefficient $\left(\mathrm{K}_{\mathrm{c}}\right)$ and basal crop coefficient $\left(\mathrm{K}_{\mathrm{cb}}\right)$ based on eddy covariance measurements of $\mathrm{ET}_{\mathrm{a}}$, the performance of both approaches was greatly improved over the two fields studied in this paper. The FAO-56 model simulation was improved by about 20 and $57 \%$ for the single approach and 24 and $49 \%$ for the dual one, over Saada 1 and Saada 2, respectively. Despite this improvement, both approaches (single and dual) still slightly overestimate $\mathrm{ET}_{\mathrm{a}}$ values for Saada 1 and Saada 2. This may be due to an overestimate of soil evaporation.

The obtained values of $\mathrm{K}_{\mathrm{c}}$ were below the FAO-56 values for both irrigation methods (flooding and drip). On the citrus orchard under drip irrigation, the average crop coefficient $\left(\mathrm{K}_{\mathrm{c}}\right)$ over the entire growing season was 0.52 , which is about $20 \%$ lower than the $\mathrm{K}_{\mathrm{c}}$ recommended by the FAO-56 method. This reduction in $\mathrm{K}_{\mathrm{c}}$ reflects the practice of drip irrigation, which reduced soil evaporation. In the citrus orchard under flood irrigation, the reduction in $\mathrm{K}_{\mathrm{c}}$ can be explained by the low value of cover fraction (about $30 \%$ ) which may reduce plant transpiration. These updated values of crop coefficients will improve future estimation of crop water requirements, and thus help to establish proper irrigation schedules and thus water use efficiency, in irrigated agriculture.

The output of the single source model is mostly dependent on one coefficient only, which means that it is difficult to adjust it when there is a balanced contribution of both the soil and the vegetation to total evapotranspiration. In the dual source approach however, one can adjust separately the contribution of the soil and the vegetation. For incomplete cover and/or drip irrigation, the dual crop coefficient seems, therefore, to be more suited since it is more flexible. Unfortunately devices to estimate plant transpiration were not available during the course of this study. Future investigations will be directed toward the assessment of the performance of the FAO-56 dual approach in terms of the partitioning of evaporation and transpiration.

\section{Acknowledgments}

This study was supported by SUDMED/IRRIMED (http://www.irrimed.org/) and PLEIADeS (http:// www.pleiades.es/) projects funded by the European Union (PCRD). We thank the CMIFM committee (Comité Mixte Inter-universitaire Franco-Marocain) for its financial support in the framework of a P.A.I. programme (2006-2009). The authors are grateful to the director and staff of the Saada citrus orchard for access and use of the field site and for assistance with irrigation scheduling and security.

\section{References}

Allen RG, Pereira LS, Raes D, Smith M. 1998. Crop evapotranspiration - Guidelines for computing crop water requirements. FAO Irrigation and Drainage Paper No. 56, Rome, Italy.

Allen RG, Pruitt WO, Wright JL, Howell TA, Ventura F, Snyder $R$, et al. 2006. A recommendation on standardized surface resistance for hourly calculation of reference $\mathrm{ET}_{0}$ by the FAO56 Penman-Monteith method. Agric Water Mgmt 81: 1-22.

Amayreh J, Al-Abed N. 2004. Developing crop coefficients for fieldgrown tomato (Lycopersicon esculentum Mill.) under drip irrigation with black plastic mulch. Agric Water Mgmt 73: 247-254.

Baldocchi DD, Law BE, Anthoni PM. 2000. On measuring and modeling energy fluxes above the floor of a homogeneous and heterogeneous conifer forest. Agric For Meteorol 102: 187-206.

Boulet G, Khabba S, Duchemin B, Chehbouni A. 2006. Simulation of the surface temperature heterogeneity prior to RS data assimilation: The Saada2/SudMed experiment. In: 2nd International Symposium on Recent Advances in Quantitative Remote Sensing (RAQRS'II), 25-29 September 2006, Valencia, Spain. pp. 216-221.

Doorenbos J, Pruitt WO. 1977. Crop water requirements. Food and Agriculture Organization of the United Nations. FAO Irrigation and Drainage Paper No. 24, Rome, Italy.

El Hari A. 1992. Besoins en eau des agrumes dans le Haouz-Effet $\mathrm{du}$ stress hydrique sur le rendement et le calibre du clémentinier [dissertation]: Diplôme d'Etudes Supérieures (DES), Faculté des Sciences Semlalia, Université Cadi Ayyad. Marrakech, Maroc. 
Er-Raki S, Chehbouni G, Guemouria N, Ezzahar J, Hadria R, Duchemin B, et al. 2006. Developing crop coefficients for olive, wheat and orange growing in semi arid region (Marrakech, Morocco). Congrès International sur la Gestion Intégrée des Ressources en Eaux et Défis du Développement Durable (GIRE3D); 23-25 May 2006; Marrakech, Morocco.

Er-Raki S, Chehbouni G, Guemouria N, Duchemin B, Ezzahar J, Hadria R. 2007. Combining FAO-56 model and ground-based remote sensing to estimate water consumptions of wheat crops in a semi-arid region. Agric Water Mgmt 87: 41-54.

Er-Raki S, Chehbouni A, Hoedjes J, Ezzahar J, Duchemin B, Jacob F. 2008. Improvement of FAO-56 method for olive orchards through sequential assimilation of thermal infrared based estimates of ET. Agric Water Mgmt 95: 309-321.

Ezzahar J, Chehbouni A, Hoedjes J, Er-Raki S, Chehbouni Ah, Bonnefond J-M, et al. 2007. The use of the Scintillation Technique for estimating and monitoring water consumption of olive orchards in a semi-arid region. Agric Water Mgmt 89: 173-184.

Ezzahar J, Chehbouni A, Er-Raki S, Hanich L. The use of the Scintillation Technique for estimating evapotranspiration ET over several agricultural fields in semi-arid regions. Plant Biosyst (in this issue).

FAO. 2003. FAO Statistics. Available: http:/apps.fao.org/ default.htm. Accessed 2003.

Hunsaker DJ, Pinter PJ Jr, Barnes EM, Kimball BA. 2003. Estimating cotton evapotranspiration crop coefficients with a multispectral vegetation index. Irrig Sci 22: 95-104.

Hunsaker DJ, Pinter PJ Jr, Kimball BA. 2005. Wheat basal crop coefficients determined by normalized difference vegetation index. Irrig Sci 24: 1-14.

Katerji N, Hamdy A, Raad A, Mastrorilli M. 1991. Conséquence d'une contrainte hydrique appliquée à différents stades phénologiques sur le rendement des plantes de poivron. Agronomy 11: 679-687.
Katerji N, Rana G. 2006. Modelling evapotranspiration of six irrigated crops under Mediterranean climate conditions. Agric For Meteorol 138: 142-155.

Rana G, Katerji N, De Lorenzi F. 2005. Measurement and modelling of evapotranspiration of irrigated citrus orchard under Mediterranean conditions. Agric For Meteorol 128: 199-209.

Schotanus P, Nieuwstadt F, De Bruin HAR. 1983. Temperature measurement with a sonic anemometer and its application to heat and moisture fluxes. Boundary Layer Meteorol 26: 81-93.

Testi L, Villalobos FJ, Orgaz F. 2004. Evapotranspiration of a young irrigated olive orchard in southern Spain. Agric For Meteorol 121: 1-18.

Twine TE, Kustas WP, Norman JM, Cook DR, Houser PR, Meyers TP, et al. 2000. Correcting eddy-covariance flux underestimates over a grassland. Agric For Meteorol 103: 279300.

Vu SH, Watanabe H, Takagi K. 2005. Application of FAO-56 for evaluating evapotranspiration in simulation of pollutant runoff from paddy rice field in Japan. Agric Water Mgmt 76: 195210.

Webb EK, Pearman GI, Leuning R. 1980. Correction of flux measurements for density effects due to heat and water vapor transfer. Q J R Meteorol Soc 106: 85-100.

Wilczak J, Oncley S, Stage SA. 2001. Sonic anemometer tilt correction algorithms. Boundary Layer Meteorol 99: 127-150.

Williams DG, Cable W, Hultine K, Hoedjes JCB, Yepez EA, Simonneaux V. 2004. Evapotranspiration components determined by stable isotope, sap flow and eddy covariance techniques. Agric For Meteorol 125: 241-258.

Yacoubi SM. 1982. Histoire et méthodologies des essais de détermination des besoins en eau des cultures au Maroc. Hommes et Terre et Eaux.
860 